\title{
Awareness and Readiness of Public Procurement officers on Sustainability in North- Eastern Nigeria
}

\author{
Ahmad Mohammed AHMAD, Muhammad-Jamil ABUBAKAR, Nafi'u Hamisu UMARU
}

\begin{abstract}
There is a growing trend worldwide, primarily developed and some developing countries, of the public sector moving from conventional procurement system towards the more sustainable and environmental-friendly approach. The need to consider economic, environmental as well as social aspects of projects before embarking on it yield enormous benefits to the present and future generations. This study seeks to assess the level of awareness and readiness of public procurement experts on Sustainability in north-eastern Nigeria. The study targeted procurements experts in Bauchi and Gombe state working at Due-process unit, a focal point that ensures efficiency, transparency and effectiveness in all procurements (goods and services), and issue certificate of compliance to across the state. A total of seventy-three (73) questionnaire forms were administered to the respondents to rank, based on their experience, social, economic and environmental factors in a Linkert-like scale of five-point. Fifty-three (53) questionnaires were returned, and Cross-tabulation was used to compare the respondents' background information, which shows that most of those with training on Sustainability are engineers with a bachelor's degree. Descriptive statistics and Friedman's ANOVA were used to, which ranked gender, race, religious discrimination, the factor with highest mean score thus ranked first, while Similar working experience, lowest responsive tender and excellent workmanship were ranked second, third and fourth respectively. Friedman's ANOVA with the stepwise step-down comparison, with a significant factor of 0.05 , ranked using energy saver appliance and fair working condition as the most significant factors. The study recommends that other geopolitical zones of the country should also embark on the same study.
\end{abstract}

Keywords: Procurements; Awareness; Readiness; Sustainability; Nigeria

\section{INTRODUCTION}

There is a growing trend worldwide, primarily developed and some developing countries, of the public sector moving from conventional procurement system towards the more sustainable and environmental-friendly approach. The need to consider economic, environmental as well as social aspects of projects before embarking on it yield enormous benefits to the present and future generations [7]. [14-16] reports that about $30 \%$ of countries Gross Domestic Product (GDP) is spent on public procurement, which, when spending wisely, can contribute to achieving sustainable development goals. The concept of Sustainable Procurement (SP), which was initially floated at the UN

Revised Manuscript Received on April 19, 2019.

Ahmad Mohammed Ahmad, Student, M. Tech, Nigerian Institute of

Muhammad-Jamil Abubakar, Federal University of Technology Minna, Nigeria.

Nafi'u Hamisu UMARU, Teacher working with Abubakar Tatari Ali Polytechnic, Bauchi, Nigeria. Quantity Surveyors (PNIQS), Nigeria.

World Summit on Sustainable Development in Johannesburg in 2002, is conceptualised to include environmental, financial and social considerations [16]. It involves looking beyond the traditional economic parameters and making decisions based on life-cycle costs, associated environmental and social risks and benefits as well as broader social and environmental implications [1516].

Sustainable development means "meeting the needs of people today without destroying the resources that will be needed by persons in the future based on long-range planning and the recognition of the finite nature of natural resources" [15]. This does not renege humanity from utilising natural resources but instead calls for more effective management of resource utilisation in other not to harm the planet or possible future users or uses of our resources [1].

Nigeria is the most populated country in Africa, which makes it vulnerable to natural disaster and other environmental instabilities. This calls for attention to balance social, economic as well as environmental issues into the procurement system to meet the present need without compromising the future generation [1].

The construction industry is aimed at delivering and maintaining the built environment [13], which comprises of housing, educational, industrial, commercial and infrastructural facilities. If countries are concerned about how economic, social and environmental criteria may be used in public procurement without harming the integrity of the process, then the practice of sustainable procurement needs to be pursued. Sustainable procurement is a process of obtaining goods or services that recognise, integrate and implement social, economic and environmental aspects throughout the process without compromising the wellbeing of the stakeholders [3]. For sustainable development (SD), it is necessary to ensure the best value for money [9]. The incorporation of economic, environmental drives sustainability, and equity-driven values and policy aimsfurther defined as people, profit and planet [15]. Sustainable Procurement (SP) worldwide is heavily driven by public procurement agendas and is often viewed as a public sector initiative. While sustainable procurement activities are prevalent in many developed countries, awareness and implementation are still comparatively low in most developing countries [9]. 
In 2007, Nigerian Public Procurement act was established by the national council on Public Procurement and the Bureau of public procurement as the Regulatory authorities responsible for the monitoring and Oversight of public procurement, harmonising the current Government practices and policies by coordinating, setting benchmarks and developing the framework for legal and Professional capacity for public procurement officers in Nigeria. While there is no emphasis on social and environmental consideration in the act, Section 7 (1) (e) emphasises on achieving value for money in all public procurement projects, yet, there is a total absence of value-for-money in Nigeria's project development matrix.

Countries such as UK, Belgium, Italy, Japan, US, Canada, Germany, the Netherlands, Sweden, Austria, Denmark, Finland, and Spain are considered front runners in implementing some form of Green/Sustainable Public Procurement [15].

\section{LITERATURE REVIEW}

\section{A. Procurement}

"Procurement is the acquirement of appropriate goods and services at the best possible 'total cost of ownership' to meet the needs of the purchaser in terms of quality and quantity, time and location. When the public sector purchases goods and services, it is called public procurement [2].” As has been rightly said, 'It is the process by which government and public sector institutions buy inputs for vital public sector investments in physical infrastructure and for strengthening human, institutional capacities, which lay the foundation for national development' [12]. With 10 to 15 per cent of the national budgets in developed countries and up to 20 per cent in developing countries, government procurement accounts for a substantial part of the economy [12].

\section{B.SustainableProcurement}

Sustainable public procurement (SPP) is a tool which allows governments across the globe to leverage public spending in order to promote their country's social, environmental and economic policies. Public procurement expenditure is 10 to 15 percent of the national budgets in developed countries, and up to 20 per cent in developing countries like Nigeria. However, the present public procurement policy in Nigeria does not formally take into account sustainability aspects. The Government of Nigeria recognises that procurement decisions by public entities, Ministries, Departments and Agencies (MDAs) have known social, public health, environmental and economic impacts both locally and globally, at present and in the future.

\section{C.SustainableDevelopment}

Sustainable development concept has received massive attention across the globe. It centres on the continuity of human existence and sets the pace for future generation. Any development that lacks the principles of sustainable development should be considered as unsustainable since only provide the framework on how to protect the environment but also the mindset on how to preserve the earth's natural resources and improve the quality of human lives [10]. The sustainable developments goals (SDGs) are as follows;

○ "End poverty in all its forms everywhere.

- End hunger, achieve food security and improved nutrition and promote sustainable agriculture.

- Ensure healthy lives and promote well-being for all at all ages.

- Ensure inclusive and equitable quality education and promote lifelong learning opportunities for all.

$\circ \quad$ Achieve gender equality and empower all women and girls.

- Ensure availability and sustainable management of water and sanitation for all.

- Ensure access to affordable, reliable, sustainable and modern energy for all.

- Promote sustained, inclusive and sustainable economic growth, full and productive employment and decent work for all.

- Build resilient infrastructure, promote inclusive and sustainable industrialisation and foster innovation.

- Reduce inequality within and among countries.

- Make cities and human settlements inclusive, safe, resilient and sustainable.

- Ensure sustainable consumption and production patterns.

- Take urgent action to combat climate change and its impacts.

- Conserve and sustainably use the oceans, seas and marine resources for sustainable development.

- Protect, restore and promote sustainable use of terrestrial ecosystems, sustainably manage forests, combat desertification, and halt and reverse land degradation and halt biodiversity loss.

- Promote peaceful and inclusive societies for sustainable development, provide access to justice for all and build effective, accountable and inclusive institutions at all levels.

- Strengthen the means of implementation and revitalise the Global Partnership for Sustainable Development."

\section{Environmental considerations}

An organisation must weigh several elements when determine on a facility location and logistic acquisition [10]. Therefore, designs should be made in a manner that minimises energy use, reduces noise and pollution and cause it more potent to generate the products required. Environmental drivers for sustainable procurement pilot the organisation towards effectual and sustainable use of available resources [4]. As such, organisations must promote the use of renewable sources of input and put significant considerations on how those resources are used in order to guarantee the availability of those resources in the future [8]. [11] stated that environmental considerations help the organisation to make a specification for green products through selecting, management and development of 
suppliers with environmental capabilities and commitments. [11] further indicated that there is also the deliberate effort put in place to reduce waste of resources throughout the sourcing cycle, minimisation of pollution, waste and emission and recycling or safe disposal of products at the end of life [4-5]. Environmental drivers of Sustainability seek to minimise any adverse environmental impacts of goods and services acquisition, across their life cycles from raw material extraction to their end of life.

\section{METHODOLOGY}

The research used a questionnaire to collect data. A total of seventy-three (73) questionnaires were administered to procurements experts in Bauchi and Gombe state working at Due-process unit, a focal point that ensures efficiency, transparency and effectiveness in all procurements (goods and services), and issue certificate of compliance with public procurement act 2007, to fill and rank them according to experience on sustainability factors (social, environmental and economy). Fifty-three (53) filled questionnaire forms were returned, which is about $68 \%$ used for analysis. The questionnaire form comprises both open and closed-ended twenty-nine (29) questions with five on the background information of the respondents. These include profession, years of experience, educational qualification, training on procurement as well as training on Sustainability. The remaining twenty-four are on factors of Sustainability on Linkert-like scale of five $1=$ not important; 2 =less important; 3 =important; 4=moderate important; and 5=very important. The collected data was cleaned, arranged, coded and fed into SPSS 21 and analysed using both descriptive and inferential statistics. Cross-tabulation was used to compare the background information, while Friedman's ANOVA was used for ranking with multiple comparisons of stepwise step-down.

\section{RESULTS}

Table 1: Cross-Tabulation of respondents' working Experience with training on Procurements

\begin{tabular}{|l|l|l|l|}
\hline \multirow{2}{*}{ Experience } & \multicolumn{2}{|l|}{ Procurements } & \multirow{2}{*}{ Total } \\
\cline { 2 - 3 } & Yes & No & \\
\hline less than 5yrs & 1 & 1 & 2 \\
5-10 years & 10 & 2 & 12 \\
11-15 years & 9 & 6 & 15 \\
16-20 years & 10 & 4 & 14 \\
above 20 years & 7 & 3 & 10 \\
Total & 37 & 16 & 53 \\
\hline
\end{tabular}

Most of these that received training and workshop on procurement has the working experience above five years. With only two (2) respondents out of fifty-three (53), this means that $96 \%$ of the respondents have working experience, which qualifies them to give reliable information

Table 2: Cross-tabulation of respondents' work experience with training on sustainability

\begin{tabular}{|l|l|l|l|}
\hline \multirow{2}{*}{ Experience } & \multicolumn{2}{|c|}{ Sustainability } & \multirow{2}{*}{ Total } \\
\cline { 2 - 3 } & Yes & No & \\
\hline less than 5yrs & 0 & 2 & 2 \\
5-10 years & 5 & 7 & 12 \\
11-15 years & 10 & 5 & 15 \\
16-20 years & 8 & 6 & 14 \\
above 20 years & 5 & 5 & 10 \\
Total & 28 & 25 & 53 \\
\hline
\end{tabular}

Table 3: Cross-tabulation of respondents' Profession with training on Sustainability

\begin{tabular}{|l|l|l|l|}
\hline \multirow{2}{*}{ Profession } & \multicolumn{2}{|l|}{ Sustainability } & Total \\
\cline { 2 - 3 } & Yes & No & \\
\hline Architect & 4 & 1 & 5 \\
Builder & 7 & 8 & 15 \\
Civil/ services engineer & 12 & 9 & 21 \\
QS & 4 & 7 & 11 \\
OTHERS & 1 & 0 & 1 \\
Total & 28 & 25 & 53 \\
\hline
\end{tabular}

With regards to training on sustainability, all those with at least five years working experience received the training on sustainability. This makes the respondents in a better position to give reliable information and will help to compare traditional and sustainable-wise procurement. 
International Conference on Recents Advancements in Engineering and Technology (ICRAET-18) |15th and 16th March 2019|Siddhartha Institute of Technology \& Sciences, Telangana, India.

Descriptive Statistics

\begin{tabular}{|c|c|c|c|c|c|c|c|}
\hline & $\mathrm{N}$ & Mean & Std. Deviation & Minimum & Maximum & mean rank & rank \\
\hline Reduce unemployment & 53 & 3.8679 & .68043 & 3.00 & 5.00 & 12.60 & 15 \\
\hline Eliminate Child labour & 53 & 4.1887 & .70864 & 3.00 & 5.00 & 15.23 & 9 \\
\hline Avoid discrimination & 53 & 4.6792 & .47123 & 4.00 & 5.00 & 18.61 & 1 \\
\hline End user participation & 53 & 3.9245 & .78076 & 2.00 & 5.00 & 13.06 & 13 \\
\hline Youth empowerment & 53 & 4.0943 & .65821 & 3.00 & 5.00 & 14.33 & 10 \\
\hline Respect for Culture & 53 & 4.2453 & .82987 & 3.00 & 5.00 & 15.61 & 8 \\
\hline Fair working condition & 53 & 2.8491 & .76952 & 1.00 & 4.00 & 6.52 & 21 \\
\hline Local community participation & 53 & 3.3396 & 64877 & 2.00 & 5.00 & 9.06 & 19 \\
\hline Low energy appliances & 53 & 2.4151 & .49745 & 2.00 & 3.00 & 4.00 & 22 \\
\hline Plastic bag & 53 & 2.2075 & .71679 & 1.00 & 3.00 & 3.55 & 23 \\
\hline Use material with less absorption & 53 & 1.8113 & .73528 & 1.00 & 4.00 & 2.58 & 24 \\
\hline Use less water & 53 & 3.3962 & .59935 & 2.00 & 4.00 & 9.03 & 20 \\
\hline Prevent bush burning & 53 & 3.9245 & .87374 & 2.00 & 5.00 & 13.45 & 11 \\
\hline Disposal of hazardous items & 53 & 3.4340 & .84374 & 2.00 & 5.00 & 9.81 & 17 \\
\hline Environmental impact & 53 & 3.3208 & 1.08793 & 2.00 & 5.00 & 9.74 & 18 \\
\hline Use less resource & 53 & 3.9245 & .85145 & 2.00 & 5.00 & 13.10 & 12 \\
\hline Lowest responsive tender & 53 & 4.6038 & .49379 & 4.00 & 5.00 & 18.08 & 3 \\
\hline Less waste in all works & 53 & 3.7925 & .71679 & 3.00 & 5.00 & 12.08 & 16 \\
\hline Good workmanship & 53 & 4.5094 & .50469 & 4.00 & 5.00 & 17.46 & 4 \\
\hline Use quality materials & 53 & 4.3962 & .53131 & 3.00 & 5.00 & 16.59 & 7 \\
\hline Discount from tenderer & 53 & 4.4717 & .50398 & 4.00 & 5.00 & 17.12 & 6 \\
\hline Similar work experience & 53 & 4.6226 & .48936 & 4.00 & 5.00 & 18.34 & 2 \\
\hline Life-Cycle Cost & 53 & 3.8679 & .68043 & 3.00 & 5.00 & 12.61 & 14 \\
\hline Value-For-Money & 53 & 4.4906 & 63919 & 3.00 & 5.00 & 17.42 & 5 \\
\hline
\end{tabular}




\begin{tabular}{|c|c|c|c|c|c|c|c|c|c|c|c|c|c|}
\hline \multicolumn{14}{|c|}{ Friedman's ANOVA WITH STEPWISE STEP-DOWN COMPARISON } \\
\hline & & \multicolumn{12}{|c|}{ Subset } \\
\hline & & 1 & 2 & 3 & 4 & 5 & 6 & 7 & 8 & 9 & 10 & 11 & 12 \\
\hline \multirow{24}{*}{ Sample ${ }^{1}$} & Use material with less absorption & 2.585 & & & & & & & & & & & \\
\hline & Plastic bag & 3.547 & 3.547 & & & & & & & & & & \\
\hline & Use Low energy appliances & & 4.000 & 4.000 & & & & & & & & & \\
\hline & Fair working condition & & & 6.519 & 6.519 & & & & & & & & \\
\hline & Using less water & & & & 9.028 & 9.028 & & & & & & & \\
\hline & Local community participation & & & & 9.057 & 9.057 & & & & & & & \\
\hline & Environmental impact & & & & 9.736 & 9.736 & 9.736 & & & & & & \\
\hline & Disposal of hazardous items & & & & 9.811 & 9.811 & 9.811 & 9.811 & & & & & \\
\hline & Less waste in all work & & & & & 12.085 & 12.085 & 12.085 & 12.085 & & & & \\
\hline & Reduce unemployment & & & & & & 12.604 & 12.604 & 12.604 & & & & \\
\hline & Life-cycle Cost & & & & & & 12.613 & 12.613 & 12.613 & & & & \\
\hline & End-user participation & & & & & & & 13.057 & 13.057 & 13.057 & & & \\
\hline & Using less resource & & & & & & & 13.104 & 13.104 & 13.104 & & & \\
\hline & Prevent bush burning & & & & & & & 13.453 & 13.453 & 13.453 & 13.453 & & \\
\hline & Youth participation & & & & & & & & 14.330 & 14.330 & 14.330 & 14.330 & \\
\hline & Avoid child labour & & & & & & & & 15.226 & 15.226 & 15.226 & 15.226 & 15.226 \\
\hline & Respect culture and norms & & & & & & & & 15.613 & 15.613 & 15.613 & 15.613 & 15.613 \\
\hline & Using quality materials & & & & & & & & & 16.594 & 16.594 & 16.594 & 16.594 \\
\hline & Discount from tenderer & & & & & & & & & & 17.123 & 17.123 & 17.123 \\
\hline & Value-For-Money & & & & & & & & & & & 17.415 & 17.415 \\
\hline & Good workmanship & & & & & & & & & & & 17.462 & 17.462 \\
\hline & Lowest responsive tender & & & & & & & & & & & & 18.085 \\
\hline & Similar work experience & & & & & & & & & & & & 18.340 \\
\hline & Avoid discrimination & & & & & & & & & & & & 18.613 \\
\hline \multicolumn{2}{|c|}{ Test Statistic } & 4.245 & .925 & 6.113 & $\begin{array}{r}11.92 \\
8\end{array}$ & 9.106 & 11.370 & 13.747 & 14.761 & 14.638 & 12.965 & 11.666 & 15.836 \\
\hline \multicolumn{2}{|c|}{ Sig. (2-sided test) } & .039 & .336 & .013 & .018 & .059 & .023 & .033 & .064 & .023 & .024 & .070 & \\
\hline \multicolumn{2}{|c|}{ Adjusted Sig. (2-sided test) } & .382 & .993 & .150 & .083 & .251 & .104 & .107 & .162 & .078 & .092 & .220 & \\
\hline
\end{tabular}

More than half (about 53\%) of the respondents received training on sustainability and out of which engineers (civil, electrical and mechanical) have about $43 \%$ followed by builders with $25 \%$ while QS and Architect have about $18 \%$ 
each. This means that issues of sustainability are expected to be handled by engineers.

Mean ranking of the sustainability factors according to the respondents indicate discrimination against gender, race, religion and ethics has the highest score thus ranked above other factors, which agrees with UNDP (2013) agenda on sustainability. Similar working experience, lowest responsive tender and excellent workmanship were ranked by the respondents as second, third and fourth, respectively. This means that issues of cost and quality parameters of projects are also considered.

The table above shows the homogeneous subset of the 24 sustainability factors. With stepwise step-down comparison, it compares the factor that has a lowest mean score with the second lowest using a significant level of 0.05 , and factors that appeared on the same column with the lowest significance, 0.013 in this case, is the most significant factor. Using appliances with low energy consumption and fair working condition, which appeared in column 3 happened to be the most significant factor. This is because most of the respondents received training on sustainable procurement are engineers, thus looked at sustainability from the engineering aspect. According to the study, $53 \%$ of the respondents are aware of sustainability, thus are ready, but the free act on procurement negate the sustainability in procurement.

\section{CONCLUSION}

The results of the study inform policymakers about current awareness and readiness status of public procurement officers on Sustainability in Bauchi state North-Eastern Nigeria and on which basis they can assess whether the current level is as desired. Finally, future research can focus on examining the awareness and readiness of public procurement officers in other geopolitical zones of the country using more large sample sizes and a different method of data collection.

\section{REFERENCES}

1. Akinola, J.A, Okolie, K.C. \&.Akinola, V. O (2013), Evaluation of Procurement Methods for Sustainable Environmental Development in Nigeria. Civil and Environmental Research

2. Bodunrin, A. K. (2016), Empirical Review and Analysis of Public Procurement Practices in Nigeria: Challenges and Prospects. Public Policy and Administration Research ISSN 2224-5731(Paper) ISSN 22250972(Online) Vol.6, No.3, 2016.

3. Bohari, A.M. (2017), Exploring the Potential for GreenOriented Procurement for Building Projects: A Case of the Malaysian Construction Industry. A PhD thesis at the Faculty of Science and Engineering, Queensland University of Technology.

4. Chartered Institute of Purchasing \& Supply (CIPS), (2012). Sustainability in Supply Chains.Lincolnshire: prose publishing.

5. DEFRA (Department for Environment Food and Rural Affairs). (2006). Procuring the Future-The Sustainable Procurement Task Force National Action Plan. Available at:

www.sustainabledevelopment.gov.uk/publications/procur ementactionplan/documents/full-document.pdf

[Download on 2 June 2018]
6. Kamruzzaman, M. (2013). Sustainable procurement: Scope and Practice in the Public Sector in Bangladesh A Master's Dissertation, BRAC Institute of Governance and Development, BRAC University, Dhaka, Bangladesh.

7. Lama, P. (2014), a case for green procurement in Bhutan, an EU funded research paper, Published by the Green Public Procurement in Bhutan (GPP Bhutan) Project, www.gppbhutan.bt

8. Lysons, K., \& Farrington, B., (2012). Purchasing and Supply Chain Management (8th ed.). Pearson Education Limited. Essex.

9. Mannan, M. A and Islam, Z. (2013). A study to assess public procurement regulations for sustainable development in Bangladesh. International Journal of Engineering, Business and Enterprise Applications (IJEBEA). 5(1):81-86.

10. Orji, U. J., (2013). Enhancing sustainable development in Nigeria: a discourse on the legal basis and proposals to strengthen legal and policy strategies for its implementation. Commonwealth Law Bulletin, 39(1), 163-197, DOI: 10.1080/03050718.2012.729338

11. Paul, C., Richard, L., Benn, L., \& Brian, S. (2008). Strategic Supply Chain Management. Essex: Prentice Hall.

12. Pratyush, Sinhu, CVC (2009) 'Enhancing Value in Public Procurement International Journal of Project Management, 24 (1), 1. ISSN 2222-1719 (Paper) ISSN 2222-2863 (Online) Vol.3, No.3, 2013. www.iiste.org

13. Turner, R. J., (2006). Towards a Theory of Project Management: The Nature of the Project, International Journal of Project Management, 24 (1), 1. ISSN 2222 1719 (Paper) ISSN 2222-2863 (Online) Vol.3, No.3, 2013. www.iiste.org

14. United Nations, (2015). Transforming our world: the 2030 Agenda for Sustainable Development. Seventieth session of the General Assembly of the united nation. $\mathrm{A} / \mathrm{RES} / 70 / 1$.

15. United Nations Environment Programme (UNEP). (2013). Sustainable Public Procurement: A Global Review. Full Report. Retrieved from http://www.unep.org/resourceefficiency/Portals/24147/S PP_Full_Report_Dec2013_v2\%20NEW\%20\%282\%29.p df.

16. United Nations Environmental Programme, (2002) World Summit on Sustainable Development, Johannesburg, South Africa www.cci.gov.in/menu/backNote091212 Public Procurement: Achieving Best value through Competition.

\section{AUTHORS PROFILE}

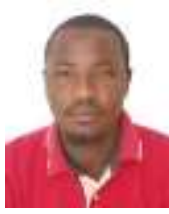

Ahmad Mohammed Ahmad had his elementary, secondary and tertiary education in Bauchi. He received a Diploma in building technology and Higher National Diploma in Quantity Surveying (QS) from Federal Polytechnic, Bauchi. He also got PGD in Education from Usman Danfodio University Sokoto, and PGD in Construction Management from ATBU Bauchi and currently pursuing $\mathrm{M}$. Tech in QS at ATBU Bauchi. Mr Ahmad is a registered teacher with Teachers' Registration Council of Nigeria, and a Probationer, Nigerian Institute of Quantity Surveyors (PNIQS), he is working with Bauchi state ministry of education.

Muhammad-Jamil ABUBAKAR is an academic staff in the Department of Quantity Surveying, Faculty of Environmental Sciences, Federal University Birnin Kebbi. He is currently a $\mathrm{PhD}$ research Student in the Department of

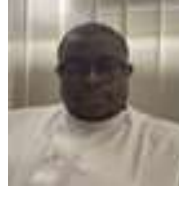


Quantity Surveying, Faculty of the Built Environment and Surveying, Universiti Teknologi Malaysia. The author obtained a Master of Science in Construction Project Management from Heriot-Watt University and Bachelor of Technology in Quantity Surveying from the Federal University of Technology Minna, Nigeria. He is a Probationer member of the Nigerian Institute of Quantity Surveyors.

Nafiu Hamisu Umaru got his elementary and secondary education in Plateau State. He also got Diploma in Building Technology and HND in QS from Federal Polytechnic, Bauchi. He got PGD IN education and another PGD in QS from ATBU Bauchi. $\mathrm{He}$ is also a registered Teacher working with Abubakar Tatari Ali Polytechnic, Bauchi. 